\title{
Estado, Identidade e Educação: cento e cinquenta anos de resistências e lutas em Cuba
}

Recebido: 27-09-2019

Aprovado: 09-12-2019

Camilo Onoda Luiz Caldas ${ }^{1}$ Maria do Carmo Luiz Caldas Leite ${ }^{2}$

\section{Introdução}

A historiografia cubana atribui grande importância à longa tradição de lutas anticoloniais, que culminaram com os feitos de $1^{\circ}$ de janeiro de 1959 , quando triunfou o processo revolucionário. Nas palavras de Harnecker (2001, p. 7) $)^{3}$, "uma luz que se acendia no escuro ambiente conservador, que então se vivia no continente americano". Essa longa trajetória começou em 1511, segundo distintos historiadores, quando o cacique Hatuey se alçou em armas contra a dominação espanhola. Outros se reportam à revolta dos afrocubanos comandados pela escrava Carlota, que ainda viva, amarrada a quatro cavalos, morreu por esquartejamento, no ano de 1844. Mas a revolução cubana começou depois da fuga de Fulgencio Batista? Ou teve início em 26 de julho de 1953, quando do assalto ao Quartel Moncada em Santiago? Ou ainda nos vários levantes da primeira metade do século XX, as

\footnotetext{
${ }^{1}$ Brasileiro. Pós-Doutor em Democracia e Direitos Humanos pela Universidade de Coimbra (Portugal). Doutor em Filosofia e Teoria Geral do Direito pela Faculdade de Direito da Universidade de São Paulo. Publicação recente: Direitos políticos de estrangeiros residentes no Brasil: crítica dos projetos legislativos no contexto migratório da América Latina. Revista eletrônica do curso de Direito da UFSM, 2018. Autor do livro Teoria Geral do Estado. 1. ed. São Paulo: Ideias \& Letras, 2018. Contato: camilo.onoda@ gmail.com

2 Brasileira. Doutoranda e mestre em Educação pela Universidade Católica de Santos (SP). Licenciada e Bacharel em Física pela Pontifícia Universidade Católica de São Paulo. Publicação: Uma análise do legado autóctone na educação cubana. Revista HISTEDBR On-line, v. 14, p. 318-332, 2015. Contato: marialcl@unisantos.br

${ }^{3}$ Todas as citações de textos escritos originariamente em Espanhol têm traduções livres realizadas pelos autores deste artigo, com algumas exceções, nas quais a tradução acarretaria a perda significativa da força de expressão própria do autor, como, por exemplo, no caso das citações de José Martí e Félix Varela.
} 
revoluções inacabadas, que não atingiram seus objetivos, mas contribuíram para a composição da identidade dos cubanos?

$\mathrm{Na}$ perspectiva do presente exercício reflexivo, a revolução cubana teve início na madrugada de 10 de outubro de 1868, quando o advogado Carlos Manoel de Céspedes, nascido em Bayamo, convocou seus escravos libertos à luta. Há uma inegável tradição de resistência em Cuba, que nasceu das revoltas contra a escravidão, tomou corpo nas guerras pela independência, enraizou-se nos movimentos contra as intervenções estrangeiras na Ilha e veio ao encontro do movimento vitorioso em 1959.

Uma análise abarcadora e com a objetividade histórica requerida sobre os processos societários em Cuba, no entendimento desta pesquisa, tem de levar em conta as raízes da autoctonia, fundadas no ideário de José Martí, nas ideias de Julio Antonio Mella e de todos os próceres da independência cubana. Os registros da sociedade produzida pelo açúcar e a história da escravidão têm interfaces de séculos com intensas marcas na sociedade cubana.

A cubanía, de raiz afro-espanhola e de vocação latino-americana, é a consolidação da nacionalidade, que vem traçando pautas às atitudes da população cubana em todas as épocas. Os processos educativos em Cuba não podem ser entendidos sem o vínculo com as empreitadas históricas, que cunharam um imaginário de vertentes relativo às lutas de liberação, desde a época colonial. O caráter cubano emergiu de uma cultura de resistência materializada nas lutas ao longo de trinta anos do século XIX, nas quais pereceram quatrocentos mil cubanos, ou seja, cerca de um terço da população da Ilha na época.

O presente artigo está vinculado à trajetória de estudos de cunho etnográfico realizados em Cuba, que permitiram o transitar entre a observação e a análise, entre a teoria e a empiria, ao longo das três últimas décadas. $\mathrm{O}$ contato dos autores com a Ilha reporta-se à década de 90, quando foram realizadas as primeiras visitas à Cidade Escolar Libertad (Havana), à Cidade Escolar 26 de Julio (Santiago de Cuba) e aos Institutos Superiores Pedagógicos em diversas províncias. As participações em encontros acadêmicos na capital cubana e o relacionamento com professores, alunos e dirigentes das organizações de massa ${ }^{4}$, em viagens de retorno entre 1999 e 2019, possibilitaram a formulação de uma postura mais profunda acerca da maior das Antilhas. O levantamento bibliográfico das investigações foi

\footnotetext{
${ }^{4}$ As principais organizações de massa em Cuba são: a Central de Trabalhadores Cubanos, a Federação de Mulheres Cubanas, os Comitês de Defesa da Revolução, a União de Jovens Comunistas e a Organização de Pioneiros José Martí.
} 
realizado através de consultas a centros de documentação, museus e bibliotecas em Havana (Cuba) e Tampa (Flórida, Estados Unidos). A discussão está alicerçada na visão retrospectiva dos dilemas e das tensões presentes nas distintas etapas das lutas contra o colonialismo e o neocolonialismo, com suas bases históricas e pedagógicas.

\section{A Mescla de Diferentes Sangues, Tradições, Sonhos e Conflitos}

El mundo tiene dos campos: todos los que aborrecen la libertad, porque sólo la quieren para sí, están en uno; los que aman la libertad, y la quieren para todos, están en otro (JOSÉ MARTÍ).

Pequena, mas centro de defesa do império espanhol, Cuba foi a ilha mais cobiçada pelos interesses de estrangeiros, que aspiravam dominar estrategicamente a região. $\mathrm{O}$ enriquecimento dos colonizadores apoiou-se na submissão imposta aos nativos, interrompendo o processo autônomo das comunidades indígenas e implantando em Cuba o regime de servidão feudal. "Na América do século XVI, os espanhóis já aplicaram o princípio da 'guerra buena' contra os naturais, acusados ora de antropofagia, ora de sodomia', no dizer de Sosa Rodríguez e Penabad Félix (1997, p. 125).

Um peculiar processo histórico, análogo ao da maioria das Antilhas, fez com que fluísse à composição da cubanidade ${ }^{5}$ um conjunto de duas correntes fundadoras: a espanhola, dos colonizadores, e a africana, dos homens escravizados. Assim, foi transplantada à Ilha a sociedade dividida em classes e a repressão do aparato colonial. Entretanto, o processo de aculturação e a violência dos conquistadores não impediu as marcas autóctones na cultura e no caráter dos cubanos. Como matriz do poder hegemônico, desde a conquista da América pelos europeus, a aculturação está baseada na usurpação, no racismo e na exclusão dos povos nativos.

Uma das características fundamentais do sistema colonial hispano-americano no processo de formação da cubanidade foi o regime agrário, sob cuja fórmula a economia cubana se voltou à especialização produtiva do açúcar, um elemento que definiria a estrutura econômica, política e social do país por mais de três séculos. O modelo escravista, de acordo com as regras impostas pelo capital comercial espanhol, dificultou a capacidade da oligarquia

\footnotetext{
${ }^{5}$ A cubanidade é o processo de intricadas transculturações, apresentando o cubano como o resultado parcial do movimento contínuo e inacabado de uma mistura, síntese e dissociação, do que foi aportado pelos que chegaram à Ilha.
} 
crioula de adaptar-se ao sistema capitalista e, consequentemente, ao avanço da industrialização e do uso de mão de obra assalariada. Uma lenta tarefa de séculos marcada por mesclas de diferentes sangues coagulou a sociedade cubana, em um complexo processo de formação: "desintegrativo e integrativo, nos elementos substanciais colocados em ação, no ambiente em que se operou e nas vicissitudes de seu transcurso" (RODRÍGUEZ RIVERA, 2005, p. 7).

O final do século XIX foi marcado por sucessivas rebeliões de escravos africanos, sobretudo na planície Havana-Matanzas, o empório da antiga oligarquia, dada a riqueza de suas terras, com um privilegiado manto freático e, em particular, com a profusão da indústria açucareira e o desenvolvimento das ferrovias. O colapso do colonialismo na Ilha era iminente, porque do ponto de vista político, todas as classes sociais do país, de forma ativa ou passiva, repudiavam o regime colonial. A burguesia açucareira cubana, ainda que colaborasse economicamente com a insurreição, estreitava seus contatos com os Estados Unidos e os instava a intervir nos conflitos. Havia chegado a hora de "encarnar a ação e a história do ethos patriótico iluminado pela poesia e pelo pensamento cubano" (VITIER, 2011, p. 42).

A guerra de 1895, apesar de ter durado três anos, por seu conteúdo radical, participação massiva do povo e lideranças transcendentes, especialmente de José Martí (18531895), superou em significados e em lições, todos os movimentos de libertação do colonialismo europeu, não apenas em Cuba, mas na América Latina. A heterogeneidade da população de Cuba foi momentaneamente eliminada em um enérgico e cruel esforço, distinto em relação a todo o restante do mundo. Segundo Martínez Heredia, 2005, p.188), "para a grande burguesia de Cuba, esta guerra foi um grave perigo e um infeliz acontecimento. Para as outras classes, foi uma provação suprema, o caminho de um país próprio, uma pátria”.

Se com suor dos negros escravos se construíram as grandes fortunas dos latifúndios, com seu espírito de rebeldia se semeou o sonho da independência. De acordo com Barnet (1977), a violência corporal no período de escravidão e durante a guerra de independência do colonialismo espanhol, não apenas impregnou na memória do povo um marcante sentimento de angústia, mas também se constituiu em forte elemento na construção da identidade do povo cubano. Após a tardia abolição da escravatura em Cuba, no ano de 1886, os fugitivos desceram das montanhas e tentaram retornar ao convívio social. No entanto, o medo da privação de liberdade os acompanhava, até porque a condição social dos outrora escravizados, mesmo após a abolição, não permitia o esquecimento da experiência traumática. 
Em 1898, faltando apenas ao Exército Libertador colher os frutos de sua vitória, os Estados Unidos intervieram na guerra contra a Espanha, impondo uma amarga experiência. Em $1^{\circ}$ de janeiro de 1899, arreada a bandeira da Espanha do Palácio dos Capitães Gerais em Havana, no seu lugar foi hasteada a bandeira dos Estados Unidos, que despontava como potência imperial. Assim estava nascendo em Cuba a condição de neocolônia.

\section{O Legado Pedagógico da Sociedade do Açúcar}

No hay Patria sin virtud, ni virtud con impiedad.

(PADRE FÉLIX VARELA)

Os estudos da sociedade cubana, formada por retalhos de diferentes culturas, origens e condições sociais, denotam a acumulação de riquezas da oligarquia submissa aos signos da aristocracia ibérica. As famílias criollas $^{6}$ foram responsáveis pela revolução agrícola, que conduziu o país à posição de primeiro produtor mundial de açúcar, constituindo a chamada plantocracia $^{7}$. Entretanto, sendo um país sem sistema escolarizado, onde apenas parte ínfima da população recebia algum ensino nos centros urbanos da época, Cuba foi a última colônia da Espanha nas Américas.

No final do século XVIII estavam criadas todas as condições históricas para a entrada em cena da cultura cubana. A filosofia, a poesia e outras manifestações artísticas atingiram o ponto para germinar como expressões autóctones. Por suposto, as ideias educativas também, muito especialmente, abriam espaço à criação de um pensamento novo. Precursor da tradição pedagógica progressista na Ilha, o sacerdote José Agustín Caballero (1762-1835) foi uma das mais importantes figuras da Ilustração Reformista Criolla, movimento de ideias que se vinculou à ampliação do setor açucareiro. Sem transformar a linguagem própria da escolástica, empregada durante os séculos XVI, XVII e na primeira metade de XVIII, o religioso despertou uma mirada diferente à história em Cuba. Lecionando no Seminário de San Carlos e San Ambrosio, resultou significativo o fato de este filósofo e educador ter ensinado aos cubanos a olhar o próprio interior, para que enxergassem as diferenças de seus

\footnotetext{
${ }^{6}$ A palavra criollo, em Espanhol, significa pessoa nascida na América, filha de país europeus, radicalmente distinto do termo "crioulo", em uso no Brasil, para designar um indivíduo negro, muitas vezes denotando preconceito.

${ }^{7}$ Plantocracia é a ordem política comandada pelos proprietários dos grandes latifúndios com plantações de cana.
} 
progenitores e pudessem conhecer, de outra maneira, a realidade social, política e cultural em que viviam. No ano de 1794, Caballero apresentou um projeto caracterizado por métodos antiescolásticos voltado à criação de escolas elementares públicas, razão pela qual é considerado "o introdutor em Cuba do sistema de ensino em que o aluno poderia desenvolver um pensamento organizado e uma aprendizagem mais sólida” (BUENAVILLA RECIO, 1995, p. 8).

A primeira geração de cubanos, que se atreveu a pensar por si mesma, tem sua figura cimeira no padre Félix Varela (1788 - 1853). Com ele, o compromisso patriótico radical alicerçou as lutas travadas na segunda metade do século XIX. Defensor da ilustração do povo, como exigência social, foi o primeiro a assumir entre os educadores cubanos uma atitude radicalmente revolucionária, em especial na crítica ao modelo escravista. Varela expressou suas ideias nos marcos da liberdade cristã, pois, para ele, as potencialidades do homem o conduziriam, infalivelmente, pelos caminhos do bem e do saber, quando dirigidas corretamente. Para Varela, estudar não era devorar livros; haveria que compreendê-los e meditar. Mais do que demandas estreitas e imediatas, o sacerdote aspirava, ao registrar as vicissitudes de sua época, à emancipação popular da sociedade comandada por latifundiários, que pensavam somente em suas caixas de café e sacos de açúcar. De acordo com González Soca e Reinoso Cápiro (2002, p. 1), Varela, um opositor do sistema escolástico de Educação, acreditava que o professor, quando mais fala, menos ensina.

A escola cubana foi renovada em seus métodos por José de La Luz y Caballero, discípulo de Varela, que, como professor, contribuiu para desenvolver a pedra angular de uma escola destinada às necessidades do país e à formação moral dos jovens, entre 1824 e 1862 . Para Buenavilla Recio (1995, p. 12), Caballero tinha uma percepção ampla do processo educativo, não restrito ao ato de instruir, mas voltado ao cultivo dos sentimentos. Nesse contexto, para a classe social dos economicamente incapazes, defendeu as escolinhas de amigos e amigas, as primeiras de base popular em Cuba, a integração racial e as manifestações iniciais de coeducação entre meninos e meninas. Os professores não tinham preparo adequado, nem licença para ensinar, ocupando uma posição marginal na sociedade.

A história da Pedagogia cubana, por mais breve e concisa, não pode ser escrita sem referências ao papel desempenhado por José Martí. A trajetória de sua vida revolucionária o fez passar por vários países, proporcionando-lhe conhecimentos avançados para seu tempo. Ainda que alimentasse a abertura de Cuba ao mundo, as suas ideias reafirmavam 
constantemente a busca de uma legítima cultura ajustada à realidade latino-americana, não mais a uma Educação com teorias eurocentristas e importadas da América Anglo-Saxônica. Para Martí, a noção de "eurocentrismo", era apreendida não só como as influências políticas e econômicas da Europa no mundo, mas, principalmente, como uma remissão ao enraizamento dos valores, que operavam na Educação. Com o avançar do século XIX, a afirmação do positivismo contribuiu para a consolidação, falsamente naturalizada e de sentido pejorativo, da ideia de latinidade, como expressão do "atraso" ou "fracasso" histórico e políticoeconômico. Nesse sentido, Martí avaliou os limites estreitos da corrente positivista que adentrou na América Latina na segunda metade do século XIX, elaborando a sua própria “concepção educativa livre, integral e multifacetada que ultrapassava as fronteiras do utilitarismo e as caricaturas de cópias e ideias de outras latitudes" (CHÁVEZ RODRÍGUEZ, 1996, p. 36).

Na concepção martiana era um fato grave a Educação seguir os padrões dos sistemas forâneos, desvinculados do contexto socioeconômico em que se aplicavam. $O$ fato de o ideário martiano, impregnado de humanismo, privilegiar os valores, tornou-se evidente em 1889, quando da publicação do primeiro número de La Edad de Oro $^{8}$, revista voltada às crianças do continente latino-americano. Com uma ternura militante, surgia a proposta de criar nos meninos de Nuestra América - ameaçados pela progressiva perda de sua identidade cultural - uma consciência anticolonialista e um alto sentido de solidariedade humana.

A obra de Martí, um dos precursores do pensamento filosófico em nosso continente, está permeada de características polifônicas, ao emprestar voz ao crioulo, ao índio e ao afroamericano. No pensamento de Martí "a inteligência americana estava no penacho indígena e quando se paralisou ao índio, se paralisou a América” (ACOSTA, 2015, p. 26).

O jornalismo, conjugado à atividade política, ocupou grande parte de suas atividades. Como professor, ganhou a vida nas fases mais difíceis, porém sua profissão foi a de advogado. Estudioso não apenas dos problemas da instrução em Cuba, mas de todos os países de continente americano, onde teve a oportunidade de viver, Martí elaborou um pensamento pedagógico, com a urgência da sonhada República. Convencido de que "Patria es humanidad", a síntese de tal ideário constitui, até hoje, um paradigma:

\footnotetext{
${ }^{8}$ A revista Idade de Ouro foi escrita por Martí, exilado em Nova York. Cada exemplar apresentava trinta e duas páginas com gravuras e ilustrações. Essa publicação conserva a vigência, mais de um século depois, dialogando com as crianças em um idioma universal, que não conhece tempo e distância.
} 
- Escola obrigatória, universal, gratuita e laica: a Educação, como direito e dever de todos, assegurava a liberdade de consciência ao professor e ao aluno. "Un pueblo de hombres educados será siempre un pueblo de hombres libres” (MARTÍ, 1975, t.12, p. 375).

- Educação científica e politécnica: o ensino das ciências e a Educação para o trabalho constituíam princípios básicos. " $Y$ detrás de cada escuela un taller agrícola, a la lluvia y al sol, donde cada estudiante sembrase su árbol" (ibid, t.8, p. 287).

- Educação para a vida: o fim primordial da Educação consistia em educar o homem e a mulher para seu momento e circunstância históricos. "La educación ha de ir a donde va la vida. Es insensato que la educación ocupe el único tiempo de preparación que tiene el hombre, en no prepararlo" (ibid, t.22, p. 308).

Ao diferenciar instrução de educação e destacar o processo dialético entre as categorias pedagógicas, Martí defendeu o princípio de que não há boa educação sem instrução. A vigência de seu pensamento, a inserção de sua obra na história política e literária de nosso continente radica no sabor de testemunho e na capacidade de indignação diante da injustiça. Para Fernández Retamar (2001), Martí não foi apenas uma variante terceiromundista do iluminismo e liberalismo europeus inspiradores da Revolução francesa, mas um intelectual e revolucionário original, que soube se nutrir da própria realidade cubana e latinoamericana para projetar um futuro diferente para sua terra e o mundo, em sentido oposto à visão eurocentrista. Talvez esse contexto tenha sido decisivo para ampliar o seu pensamento e levá-lo para além dos limites do liberalismo, que efetivamente o havia influenciado desde o início de sua formação.

No início da última década do século XIX, as condições de Cuba anunciavam a proximidade de uma nova guerra, que Martí classificava como necessária. Dedicando-se exclusivamente à tarefa revolucionária, ele compreendeu com agudez os problemas reais de seu país. Para tal, conclamava a união de todas as forças vivas a lutarem “con todos y para el bien de todos" ". Suas ideias transitavam entre as duas margens do Atlântico e a dedicação à causa emancipacionista fez com que passasse a maior parte de sua vida no exílio, peregrinando por vários países. Martí, em meio aos seus pensamentos e ações, analisou com clareza a dominação implícita na falsa dicotomia em uso no seu tempo: "no hay batalla entre

\footnotetext{
${ }^{9}$ Extraído do discurso pronunciado por Martí no dia 26 de novembro de 1891 em Tampa, EUA.
} 
la civilización y la barbarie, sino entre la falsa erudición y la naturaleza" (MARTÍ, 1975, t. 6. p 17).

Finalmente, em 31 de janeiro de 1895, Martí saiu dos Estados Unidos para uma viagem a Cuba da qual jamais retornaria. Após breve encontro com tropas espanholas no vilarejo de Dos Ríos, em 19 de maio do mesmo ano, ele foi morto e seu corpo mutilado. Sua morte parece ter sido um ato voluntário, tal como ele sempre desejara: "Yo soy bueno, y como bueno, moriré de cara al Sol!" 10 . Martí defendia a ampla ideia de liberação nacional, não apenas dos cubanos, mas para toda a Nuestra América. Com o exército mambí ${ }^{11}$ dissolvido, o povo foi arrastado à miséria, uma vez que a luta contra o colonialismo não culminou com a vitória.

Para Varona Domínguez (2013), a revolução que concebeu Martí, desalienadora desde sua medula, apresentava um matiz anti-imperialista, que foi tomando seu pensamento na medida em que conheceu os Estados Unidos. Apesar das críticas à pretensão hegemônica desse país sobre a América Latina, a partir de um estudo detalhado da sociedade estadunidense, Martí adentrou em sua história, sem formar uma única ideia, porque, segundo ele, em um emaranhado sociocultural, em uma composição heterogênea havia contradições, inclusive irreconciliáveis, que anunciavam a possibilidade do surgimento de uma nova forma de dominação e exploração dos povos, que posteriormente seria conhecida como neocolonialismo. Indiscutivelmente, ele possuía um referencial teórico - que evoluiu historicamente - no qual a educação é concebida como uma estratégia para o desenvolvimento do homem. Martí entendeu, sem menosprezar, nem ignorar as experiências forâneas, que o povo cubano deveria ser capaz de extrair de si, de sua história, de suas características socioculturais, o que haveria de ser sua república, em clara negativa ao legado epistemológico do eurocentrismo.

\footnotetext{
${ }^{10}$ Trecho de Versos Sencillos XXIII de José Martí, publicados em New York no ano de 1891. Os estudiosos da música da cubana afirmam que Joseíto Fernández foi o primeiro a cantar e a gravar Versos Sencillos, com a melodia da canção Guantanamera.

${ }^{11}$ Mambí é o termo com que se denominava, no século XIX, aos insurretos contra Espanha.
} 


\title{
A República Mediatizada
}

\begin{abstract}
El patriotismo es un deber santo, cuando se lucha por poner la patria en condición de que vivan en ella más felices los hombres. Nace este periódico, a la hora del peligro, para velar por la libertad, para contribuir a que sus fuerzas sean invencibles por la unión, y para evitar que el enemigo nos vuelva a vencer por nuestro desorden (JOSÉ MARTÍ).
\end{abstract}

Ao longo das décadas de 1880 e 1890, um expressivo contingente de famílias cubanas se uniu à força de trabalho assalariada nos Estados Unidos, incluindo um número crescente de mulheres em Tampa e Cayo Hueso, que aceitavam empregos humildes para sobreviver. Ir ao Norte parecia ser a ambição de todo jovem cubano. As donas de casa trabalhavam como lavadeiras, costureiras ou cozinheiras. As criollas cubanas admiravam a liberdade com que as mulheres norte-americanas podiam comprar, passear e viajar sozinhas, porque nada disso era permitido em Cuba. Durante esses anos, os cubanos de todas as classes sustentaram um prolongado encontro com os diversos segmentos culturais vigentes nos Estados Unidos, que ficaram indelevelmente marcados na construção da nacionalidade cubana. Muitas transformações ocorreram como resultado da vida no estrangeiro, num esforço em participar e fazer os ajustes necessários às necessidades cotidianas. Como manifestaria o general Máximo Gómez, em 1888, "os cubanos têm uma grande facilidade para assimilar imediatamente ao país aonde vão" (PÉREZ JR, 2016a, p. 50).

O ano de 1900 iniciou-se em Cuba com um conjunto de imposições decorrentes da primeira intervenção militar dos Estados Unidos no país. A nação popular, independente, soberana e justa que sonhara Martí, nas palavras de Cantón Navarro (2008, p. 128), "uma república que formasse seus cidadãos para o patriotismo revolucionário, o internacionalismo $^{12}$, a autoctonia e contra toda a injustiça”, deu lugar à denominada república mediatizada ${ }^{13}$.

Segundo Pérez Jr (2016b), Cuba ocupa um lugar especial na história do imperialismo norte-americano porque foi uma espécie de laboratório para o desenvolvimento de seus métodos na criação global. As consequências da intervenção Estados Unidos em Cuba

\footnotetext{
${ }^{12} \mathrm{O}$ internacionalismo é visto atualmente pelos cubanos como a antítese do bloqueio, uma questão de dívida com a sociedade. Tem suas raízes nas guerras de independência e na contribuição que indivíduos nascidos em outros países, deram nos campos de batalha, com espírito altruísta. É comum os cubanos afirmarem, quando desejam destacar a sua coragem, aliada à gratidão, que Cuba foi o país que mais aportou voluntários ä guerra civil espanhola.

${ }^{13}$ República mediatizada ou Seudo-república são termos que os cubanos utilizam para denominar a República, que nasceu em 1902 e terminou em primeiro de janeiro de 1959.
} 
tiveram um impacto decisivo na forma pela qual os estadunidenses projetam seu poder para fora de suas fronteiras. Essa ação foi celebrada como resultado das qualidades que os estadunidenses mais admiravam em si: o apoio à liberdade, como uma questão imanente, ou seja, deles próprios, e a convicção de que seus propósitos morais eram a razão suficiente para impulsionar o uso da força em outros países. Quando se somam os meios utilizados pelos vizinhos do norte na Ilha, observamos um microcosmos da experiência imperial no mundo: ocupação militar; elaboração de uma constituição; penetração do capital e saturação cultural; instalação de regimes títeres; organização de exércitos, que atuem em seu nome; estabelecimento de base permanente; assistência econômica ou a sua negação, segundo as circunstâncias. Tudo o que empreende na atualidade, o imperialismo já havia praticado em Cuba.

A situação econômica em Cuba era típica de um país neocolonial e agrário onde coexistiam relações pré-capitalistas e capitalistas, fundamentadas num escasso desenvolvimento do capital nacional e na penetração do capital estrangeiro monocultor, monoexportador e atado às necessidades econômicas dos Estados Unidos da América. Esse contexto tomou corpo, pois "as ações imperialistas se materializam na intervenção de Estados sobre outros e caracterizam a realidade do século XX, sendo o mais comum que os países do centro do capitalismo realizem tais práticas em relação aos países da periferia econômica" (CALDAS, 2018, p. 159).

Conhecido como o pioneiro do pensamento marxista em Cuba, Carlos Baliño (18481926), provavelmente conheceu Martí em Cayo Hueso, no ano de 1888, onde trabalhou como vocal $^{14}$ do Gremio de Escogedores. Cada fábrica tinha um pequeno estrado em madeira, bem visível a todos, onde o leitor se instalava. Muitas vezes o posto de leitura transformava-se em tribuna ideológica, o que molestava aos proprietários das fábricas e, sobretudo, ao colonizador espanhol. A princípio, os proprietários opunham-se à ideia, mas acabaram por perceber que o vocal garantia certo nível da paz nas indústrias. Entusiasmados com as aventuras que os livros escondiam, muitos operários decidiam aprender a ler e a escrever, fazendo dos funcionários das tabaqueiras uma das categorias operárias mais cultas no final do século XIX.

\footnotetext{
${ }^{14}$ Vocal, segundo a ideia comum entre os cubanos, é uma das melhores profissões do mundo, em que é possível ler enquanto se trabalha. Hoje, são cerca de 300 os leitores nas fábricas de charutos cubanos. De manhã, a imprensa diária, pela tarde um clássico da literatura, sobretudo os romances, como Os Miseráveis de V. Hugo, que ajudam a alimentar a consciência social dos trabalhadores. As poesias de García Lorca, o drama de Romeu e Julieta de Shakespeare e as aventuras de Dumas em O Conde de Monte Cristo estão entre os mais populares.
} 
Os acontecimentos assumiram múltiplas expressões na medida em que os cubanos buscavam novas formas de articular sua insatisfação com a dominação neocolonialista. Por sua militância e aversão patronal, Baliño foi obrigado a abandonar o bairro dos tabaqueiros em Tampa. Percorreu o sul dos Estados Unidos, período durante o qual se relacionou com trabalhadores socialistas. Ao conhecer os textos marxistas compreendeu que a problemática cubana não se reduzia tão somente a lograr a independência do colonialismo, mas que também em reverter a ordem social imperante. Finalizada a guerra necessária, sem a obtenção da real independência, Baliño regressou a Cuba, vinculando suas lutas às causas do proletariado e à defesa de uma sociedade sem classes, baseada na socialização dos meios de produção, em concomitância com o pensamento de Martí. A sua vida foi uma demonstração do entrelaçamento histórico entre marxistas e martianos. A grande mostra da carga humanista de Baliño foi a publicação de um texto, em 1925, motivado pelos suicídios de crianças trabalhadoras da indústria têxtil, no Estado de Massachussets. Nessa época, a tuberculose era frequente entre os impúberes, inclusive em menores de seis anos, que trabalhavam diariamente por mais de 14 horas. Baliño (1976, p. 169) apontou a existência de homens e de mulheres, que se assombravam ao escutar tais narrativas, porém se espantavam muito mais quando se dizia que essa tragédia é um efeito que não pode se suprimir, se não se suprime a causa fundamental e única, o abominável regime que consagra o direito à propriedade acima do direito à vida.

Somente nas duas primeiras décadas da república, a população da Ilha praticamente dobrou, atingindo a casa dos três milhões. A convulsão econômica provocada pela Primeira Guerra Mundial aumentou de forma abrupta os preços do açúcar no mercado mundial, convertendo Cuba num polo atraente ao mercado estrangeiro e de imigrantes em busca de trabalho. Um fluxo significativo de espanhóis criou as condições para a exploração obreira na indústria agrária exportadora.

O triunfo da Revolução Socialista de 1917 repercutiu em toda a América Latina. A partir dessa data, entre as consignas dos trabalhadores, surgiram novas vinculações das teorias revolucionárias às lutas no continente. $\mathrm{O}$ ambiente de renovação cultural vivenciado em Cuba, a partir de 1920, implicou a redescoberta das raízes autóctones dos embates contra a dominação estrangeira. Grandes movimentos proclamados pela juventude na América Latina do período pós-primeira guerra empreenderam um forte traço geracional, que favoreceu as lutas pela recuperação do ideário martiano. Nos anos seguintes, diversas correntes 
revolucionárias resgataram do esquecimento a que haviam sido submetidos os ensinamentos de José Martí. Os professores cubanos forjaram nas novas gerações os ideais de soberania nacional e o rechaço à opressão, em concomitância com as péssimas condições de trabalho e do ensino público.

Durante a República, começou a produzir-se paulatinamente a recuperação da imagem de Martí, que cresceu através da transmissão oral vivenciada pelos herdeiros do frustrado projeto independentista. O ideário pedagógico de Martí manteve-se na palavra cotidiana dos professores que inscreveram na memória das crianças seus Versos Sencillos, Zapaticos de Rosa e La Historia de la Niña de Guatemala: "Junto aos versos, levantou-se a figura do herói, que deveria haver sobrevivido para construir a república sonhada. Com essa recordação viva, começou a alimentar-se, novamente, a utopia" (POGOLOTTI, 1995, p. 5).

A vitória da Revolução Russa e a crise de 1929 pareciam desacreditar as perspectivas do liberalismo e ampliar as expectativas de um ambiente cultural renovador. Cuba, nesta época, viveu o ápice da indústria açucareira, marcada pela avassaladora entrada do capital norte-americano, que a conduziu a um processo de modernização de infraestrutura das principais cidades e o acirramento entre distintos projetos de nação. Com o distanciamento dos costumes europeus, a classe privilegiada em Cuba se deixou levar por ideias e costumes norte-americanos, a medida em que os trabalhadores eram subjugados. Tudo era digno de ser imitado aos olhos das famílias dos latifundiários. A política da oligarquia criolla, a partir da crise globalizada do modelo neocolonial, passou a restringir a produção agrícola e industrial à esfera açucareira, mediante a cartelização.

A efusão modernizante da capital cubana não conseguiu conter a escalada de conflitos oriundos de setores populares e se produziu uma ruptura no estado de letargia dos movimentos de trabalhadores e de organizações estudantis. Julio Antonio Mella (1903 1929) fez parte de uma geração de cubanos nascidos durante a transição da colônia à república, que "tomou consciência de que a oligarquia, submetida ao imperialismo, havia traído a causa do mais honesto e radical mambisado, particularmente do legado democrático e revolucionário de Martí" (CANTÓN NAVARRO, 2008, p. 138).

A Federação Estudantil Universitária, por ele fundada em 1922, surgiu no calor das reformas universitárias desenvolvidas na América, que defendiam a autonomia na universidade, a participação estudantil e o reconhecimento do direito de organização dos alunos. A similitude entre as ideias de Martí e Mella com relação aos problemas de Nuestra 
América apontava à imprescindível união dos povos ante a ameaça do imperialismo. Inspirado nas palavras de Martí (1975, t.19, p. 375), - "al venir a la tierra, todo hombre tiene derecho a que se le eduque, y después, en pago, el deber de contribuir a la educación de los demás"-, em 1923, no $1^{\circ}$ Congresso Nacional Revolucionário de Estudantes, Mella tomou a iniciativa de organizar escolas para adultos, de caráter gratuito, e participou da construção da Universidade Popular José Martí, com o objetivo de levar às camadas excluídas da sociedade o que deveria ser a herança de todos os seres humanos: a cultura livre.

No ano de 1925, quando da fundação do antigo Partido Comunista de Cuba, Mella insistia que era necessário meditar acerca da adaptação criativa da essência do marxismo, dada pelo método dialético, às condições históricas específicas da Ilha e à busca de soluções num processo autóctone. Assim, foi principalmente através de Baliño e Mella que houve um esforço em valorizar a tradição nacional, a partir da integração do ideário democrático e patriótico de José Martí às ideias de Marx, Engels e Lênin. Em 1926, Mella foi expulso da Universidade em razão de suas atividades revolucionárias, ocasião em que fez uma greve de fome. Após este fato, se exila no México e funda a Associação de Novos Emigrantes Revolucionários Cubanos.

Depois da morte prematura de Mella, assassinado na capital mexicana, o pensamento marxista em Cuba passou a ter o seu expoente máximo em Rubén Martínez Villena (1899 1934), um dos mais destacados intelectuais comprometidos com o pensamento marxista hispano-americano. Transcorria o ano da grande crise econômica de 1929, que refletiu no estancamento da indústria açucareira, das fábricas de tabacos, do turismo e da exportação de frutas, a qual se somou à excessiva carga fiscal para enfrentar as dívidas com os banqueiros dos Estados Unidos.

Nas três primeiras décadas do século XX, observou-se uma acelerada penetração na economia cubana de grupos financeiros dos Estados Unidos. Para Cirules (1994, p. 16), a capital cubana ofereceu-se à máfia norte-americana como "o mais esplendoroso dos paraísos", com o turismo e os jogos ilegais organizados. Esse tipo de negócio cresceu de tal maneira que Cuba era considerada um importante centro da delinquência internacional e a Meca da pornografia.

Na segunda década da República neocolonial, os movimentos populares de massa e as organizações políticas começaram a agitar-se de forma ativa e a decorrência foi a eclosão de uma nova revolução em Cuba nos anos 1930. Essa situação fez recrudescer as medidas 
antipopulares e a força repressiva contra os setores progressistas na Ilha. Uma das reivindicações centrais da Revolução de 30 era a abolição da Emenda Platt ${ }^{15}$. Contudo, este movimento teve um significado transcendental na história de Cuba: o de vincular os nexos da libertação nacional ao projeto socialista e de unir o projeto martiano às ideias marxistas.

Este momento trouxe resultados frutíferos ao setor do magistério, não em termos de logros materiais, mas pela proximidade das lutas da Educação com a classe obreira. Villena, convencido de que as revoluções não são obra de um líder máximo específico, mas de um grupo de homens unidos, compreendeu que não bastava protestar contra a desonestidade para construir uma pátria verdadeiramente humanista, mas era necessário educar o povo para a emancipação. Contudo, a Educação converteu-se na república mediatizada em um instrumento de norte-americanização. Os Estados Unidos ensaiaram em Cuba uma nova forma de dominação colonial, de acordo com o interesse dos interventores. A capacidade das estruturas estadunidenses para reordenar a ordem moral e a base material da vida na Ilha se incrementou de tal forma, que a relação entre Cuba e o grande vizinho do Norte adquiriu uma nova lógica de dominação.

Por suposto, a Educação jogou um papel importante neste contexto. Nas décadas dos anos de 20 a 40 do século passado, constatou-se a existência de uma luta ideológica e política, entre duas tendências pedagógicas contrapostas: de um lado, a democrática e progressista, que representava os interesses do povo, e, do outro, a tendência pedagógica reacionária, das classes dominantes. O movimento estudantil cubano, formado por estudantes rebeldes, em geral independentes de partidos, alcançou o ápice do seu prestígio durante este período.

As escolas públicas permaneciam na desordem e no desprestígio durante a república mediatizada. Desacreditado entre os cubanos de todas as classes sociais, o sistema educativo estatal se expandiu sem a confiança do povo, visto como incapaz de preparar os jovens para os desafios do futuro. Nas mais afamadas escolas privadas se matriculavam tanto estudantes da comunidade norte-americana, como cubanos oriundos da classe média. O programa e as atividades extracurriculares, se baseavam no ambiente escolar norte-americano. Para os esportes se organizavam equipes masculinas e femininas de baseball, volleyball e

\footnotetext{
${ }^{15}$ A chamada Emenda Platt oficializou o direito a intervenções militares em Cuba e autorizava o governo dos Estados Unidos a arrendar as terras necessárias para bases navais na Ilha. A emenda foi provada em 2 de março de 1901, pelo Senado dos Estados Unidos, e convertida em apêndice da Constituição cubana de julho do mesmo ano. Posteriormente foi ratificada em forma de tratado no ano de 1903.
} 
basketball. Durante mais de cinco décadas, milhares de estudantes cubanos se formaram nesse ambiente, desde o grau primário até o pré-universitário.

As aspirações da classe alta cubana estavam em Nova Iorque, o "lugar das lojas mais chiques do mundo". O desterro era uma espécie de predestinação. A experiência era tão familiar que se incorporou como uma parte normal da condição cubana. A prática tomou a forma de migrações cíclicas: durante os bons tempos em que havia condições financeiras para viajar e nos maus tempos, quando tinham necessidade de procurar melhores condições de trabalho e estudo. O "Norte" era o lugar onde os cubanos se formavam e regressavam "feitos". Na década de 1930, estima-se que 40\% da população cubana viveu nos Estados Unidos, em algum momento de sua vida. A alta burguesia de Cuba pré-revolucionária, sob essa influência, batizava aos seus membros de Billy, Joe e Bob. Falavam inglês e eram especialistas em intrigas da sociedade norte-americana. $\mathrm{O}$ regresso era, com frequência, doloroso. Ao voltar a Cuba queriam que a Calle Obispo fosse a Broadway e o Centro Havana fosse um downtown.

A penetração da língua inglesa se converteu em motivo de debates. Um setor da sociedade se inquietava com a gritante invasão cultural, que, aos poucos, solapava as tradições e os valores da cubanía. Os cinemas se chamavam Majestic e Roxy. As lojas eram Miami Store e Fifth Avenue. A bodega era grocery e o salão de beleza conhecido como beauty-parlor. Os edifícios rascacielos tinham o nome de penthouse. Diante dessa caracterização, sempre sensíveis, os cubanos reagiram com indignação. Um povo, que havia se proposto a estar na vanguarda da civilização ilustrada, encontrava-se - desde março de 1952 até janeiro de 1959 - nas mãos da ditadura corrupta de Batista, mas as narrativas sobre a nacionalidade estavam tomando forma na indignação dos cubanos. "Creem que somos um país atrasado, que não merece atenção, que não estamos capacitados para a democracia e que não podem atuar de outra maneira diferente da que praticam contra nós" (PÉREZ JR, 2016a, p. 535).

Como havia ocorrido durante a frustrada revolução dos anos 1930, o ideário martiano voltaria a ser empregado, novamente, para fundamentar a necessidade de uma revolução nacional em Cuba. Dada a tradição de rebeldia, que desde a época da colônia caracterizou o oriente de Cuba, um grupo de insurgentes decidiu atacar os quartéis de Santiago, sob o comando de Fidel Castro. Em diversas ocasiões, os setores progressistas da Ilha já haviam manifestado o rechaço à inoperância da oposição legal ao regime de Batista, que se limitava a 
denúncias no âmbito do congresso. Foi a partir deste contexto que Fidel e um pequeno destacamento, autodenominado Generación del Centenario, de diversas procedências sociais, adotou a estratégia insurrecional. Para esses jovens, era impossível tolerar passivamente que, 100 anos depois do natalício de Martí, reinasse na nação cubana o despotismo e que isso sucedesse sem resistência, como o próprio Apóstolo da independência demonstrara desde sua infância.

Nos últimos meses de 1958, diante das investidas do vitorioso exército rebelde, os arrivistas das forças de Batista trataram de buscar um lugar favorável aos seus interesses. Então, organizaram conspirações de última hora, contra o barco que estava para afundar. Com elas, alguns pretendiam dar, quando menos, um golpe de efeito. Alguns destes oportunistas manifestaram seu apoio irrestrito à causa revolucionária ao que prontamente Fidel sentenciou: “Foram purificados pelo Jordão da revolução” (FERNÁNDEZ ÁLVAREZ, 2018, p. 85).

\section{A Revolução Cubana: 60 anos de acertos e retrocessos}

La revolución quiere alas; los gobiernos pies (JOSÉ MARTÍ).

Desde o presídio na antiga Isla de Pinos, no início de 1954, onde cumpria uma pena de 15 anos pelo assalto ao Quartel Moncada, Fidel escreveu uma carta, narrando a sua experiência sobre as injustiças, que vislumbrava na vida cotidiana em Cuba de então, e de maneira particular sobre uma visita, realizada no início do ano de 1953, à escola rural, onde começou a estudar, quando ainda não havia completado 5 anos. Na missiva, ele apontava que: “Tudo o que se fizer relativo à técnica e à organização do ensino, nada vale a pena se não se alterar de maneira profunda o status quo econômico da nação, ou seja, da massa popular, que é onde está a única raiz da tragédia" (BLANCO CASTIÑEIRA, 2018, p. 21).

O triunfo da Revolução, em $1^{\circ}$ janeiro de 1959, produziu-se num momento de esplendor da cultura cubana, em que as onipresentes formas norte-americanas de viver eram submetidas a um escrutínio constante. Fernandes (2007, p. 126), afirmou que a guerrilha do Movimento 26 de Julho representava muito mais que uma luta armada. Era a outra face da guerrilha. A sociedade cubana vivia um clímax revolucionário, dava ares de fragilidade, mas era imbatível, porque se tornara a parteira de uma guerra civil, que se adiara no tempo, mas não em sua potencialidade revolucionária. 
Entretanto, como afirmou Martí (1975, t. 13, p. 269), “pelear é uma coisa e governar é outra”. As formas políticas ideológicas adotadas pelo nascente movimento obreiro não surgiram do nada, mas buscavam resgatar as tradições revolucionárias dos noventa anos de lutas pela independência. A revolução não escapou ao sentido político penetrante de Martí, de que o grave problema com o qual as nações americanas se confrontariam era a herança colonialista centenária, cuja anulação exigia uma árdua tarefa de reeducação, que despertaria nas massas novos valores retirados da realidade.

Para Fernandes (2007, p. 80), em uma sociedade neocolonial, não havia como levar a revolução para dentro do capitalismo. Cuba estava cindida entre duas forças sociais antagônicas. De outro lado, os peões miseráveis vítimas preferenciais dessa ordem, que os colocava em condições de vida regidas pelo consumo predatório da força de trabalho, juntamente com a miséria, a fome, as doenças, o analfabetismo e nenhuma perspectiva de superação de tais condições. Por outra parte, as chamadas "classes possuidoras nativas", voltadas para o mundo exterior, partícipes do processo de "americanização de Cuba", sob o signo da subserviência aos ditames dos centros de poder internos e externos.

Todas as correntes na maior das Antilhas buscavam a libertação nacional, ainda que os revolucionários ao descer de Sierra Maestra não explicitassem a sua clara opção ideológica, o que foi se definindo no desenrolar dos anos. Perante a impossibilidade de encontrar saídas para as contradições da ordem social neocolonial, tornou-se inadiável a construção de um rumo socialista para Cuba. Para aprofundar o processo revolucionário, fez-se urgente superar as relações mercantilizadas do passado e os interesses contrarrevolucionários burgueses.

Na alvorada de 26 de julho de 1953, o assalto ao Quartel Moncada em Santiago de Cuba havia inaugurado um novo período para a Educação na Ilha. O centenário natalício de Martí retratava um quadro de desmandos e desatenção em relação aos serviços educacionais. De acordo com o Ministério da Educação (CUBA, 1999, p. 9):

Apenas $56,4 \%$ das crianças frequentavam a escola primária e apenas $28 \%$ dos jovens continuavam no ensino médio. A Educação Especial, para impedidos físicos e mentais, era virtualmente inexistente. Para a formação de professores, havia seis escolas normais oficiais e três faculdades de Educação em Cuba. Em todo o país, havia mais de meio milhão de crianças sem escola e mais de um milhão de analfabetos.

Nas duas décadas, que antecederam o triunfo da revolução, ocorreu a consolidação de um vasto campo intelectual no seio das elites cubanas, marcante na cultura da América Latina. Contudo, a radicalização socialista cubana transformou os rumos desse dinamismo por 
meio de um novo posicionamento crítico sobre os latino-americanos e seu lugar na História. Enquanto reduzia os campos ideológicos da multiplicidade de discursos, o movimento revolucionário destruía as hierarquias do antigo regime, com profundas reformas nas estruturas econômicas, e alargava o acesso aos bens da cultura: "Las revoluciones son estériles, cuando no se firman con la pluma en las escuelas y con el arado en los campos" (MARTÍ, 1975, t.7, p. 163)

A primeira etapa da Revolução acarretou mudanças que estabeleceram novos fundamentos educacionais, inspirados em Martí, com alicerces na autoctonia. O grande desafio foi a alfabetização, cujos passos iniciais ocorreram no período da luta insurrecional, a partir de 1956. Os movimentos alfabetizadores, trazendo dimensões de epopeia, constituíram uma fonte motivadora, que iriam transformar socialmente a nação: “A pátria, que estava nos textos, subitamente encarnou quando um raio de justiça colocou cada qual em seu exato lugar" (VITIER, 2011, p. 212).

A criação das bases de um novo modelo tentava transformar a saúde, a educação e a cultura em direitos de toda a população. As campanhas de alfabetização começaram na etapa da luta insurrecional, quando os guerrilheiros em Sierra Maestra deveriam ser difusores de cultura, além de combatentes, levando o conhecimento aos lugares mais intrincados. A busca do homem novo, pela reapropriação da natureza humana, tornou-se o centro de mobilização da sociedade, que pensava em converter-se numa grande escola. "Depois da revolução cubana deu-se máxima prioridade à educação e à saúde" (UNESCO, 2005, p. 57)

Em 14 de setembro de 1959, o antigo acampamento militar de Columbia, o principal reduto de Batista, foi transformado na Cidade Escolar Libertad. Com essa ação, os postulados do programa Moncada começavam a ser cumpridos. A população entendeu, desde o início, que os revolucionários não apenas falavam que a Educação seria priorizada, mas já estavam colocando em prática suas ideias. A meta mais ambiciosa foi a erradicação do analfabetismo em 1961, o “Ano da Educação”. A Campanha de Alfabetização teve seus antecedentes na época do colonialismo, como reflexo de um pensamento autóctone, quando o exército dos mambises vinculou a aprendizagem da escrita e da leitura à formação dos valores patrióticos. Em 1896, com a publicação El cubano libre editou-se "a primeira cartilha voltada ao desenvolvimento de uma consciência participativa na vida político-social”, segundo Canfux Gutiérrez (2006, p. 1). 
A relação que estabelecera Martí, em 1884, entre cultura, educação e emancipação "ser culto é o único modo de ser livre" (MARTÍ, 2011, p. 52) -, serviu de base para a concepção de um sistema de Educação orientado por novos fundamentos. A campanha desencadeou-se com o chamamento de voluntários para a tarefa de alfabetizar. Participaram milhares de estudantes, operários, alfabetizadores populares e professores, o que possibilitou a criação de documentários, poesias, canções e análises dos interessados em compreender as razões que ensejaram a mobilização das massas de forma organizada. Esta experiência configurou-se como o primeiro vínculo da educação à vida política após a revolução, pois os alfabetizadores compreenderam as desigualdades sociais e conscientizaram-se da necessidade de superação dos graves problemas que afetavam o país.

Após 1961, com as reformas iniciadas, foram implementados novos elementos aos conceitos de formação emergente e de professor como militante político. A urgência na formação dos professores foi decorrência da ampliação dos serviços educacionais aos níveis superiores. Procurou-se organizar medidas práticas, na fase denominada de Ativismo Pedagógico, que transcorreu durante os anos de 1960, quando as ações na área educacional se fundaram na ideia "quem sabe mais, ensina quem sabe menos". Muitas medidas de cunho imediatista vigentes nesse período demandaram reformulações nas décadas seguintes.

A formação de maestros e professores transitou por diferentes etapas a partir de 1964, quando foram fundados os Institutos Superiores Pedagógicos, com o objetivo de dar resposta à necessidade crescente de docentes para o nível médio. Milhões de operários, camponeses, donas-de-casa puderam ascender, no quinquênio 1976-81, ao sexto grado. Posteriormente, no transcurso da década de 80, ao nono grado de escolarização.

Com a solidificação das relações comerciais entre Cuba e a URRS, a principal opção no enfrentamento ao bloqueio imposto pelos Estados Unidos, incluíram-se nas diretrizes societárias cubanas os aportes das experiências socialistas, alicerçadas nas formulações do marxismo-leninismo. As raízes pedagógicos passaram a ser fortemente influenciados pelo ideário pedagógico de Martí, imbricado com contribuições teóricas de Marx e Engels sobre o trabalho e o coletivismo, acrescidas das formulações dos soviéticos Makarenko e Vigotski, em conformidade com desenvolvimento sócio-histórico do homem, manifesto pelas necessidades geradas em cada época, com a perspectiva histórica e cultural da realidade dos povos América Latina e Terceiro Mundo (CHACÓN ARTEAGA, 2017). 
A Segunda Revolução Educacional em Cuba veio como resultado dos programas de massificação do acesso às escolas de todos os graus, quando se incrementaram os cursos de licenciatura nas diversas áreas. A explosão de matrícula, decorrência do processo universalização do ensino, implicou no aumento acelerado do sistema educativo. Em 1969, a União de Jovens Comunistas organizou a campanha "Yo seré maestro". O governo teve que recorrer aos cursos intensivos, com incorporação imediata dos docentes à prática escolar. Os professores emergentes foram denominados de "los makarenkos".

Os problemas típicos de uma rede em expansão revelaram-se no processo cubano, o que induziu a procura de novos fundamentos para a articulação do Sistema Nacional de Educação. As decisões, com tendência à centralização, conformaram uma estrutura encarregada de transmitir no sentido vertical - até as bases - as diretrizes elaboradas por níveis superiores. Com a autonomia limitada, as instâncias intermediárias tinham pouco espaço de ação. O efeito imediato dessa estrutura concentrou-se em deficiências no protagonismo dos professores, conduzindo ao enfraquecimento da criatividade e da iniciativa própria. A tomada das decisões no campo educacional, a partir do processo revolucionário, em especial nas décadas de 60 e 70 do século passado, demonstrou uma tendência à centralização política. Esta etapa de consolidação da Revolução Cubana ocorreu em um momento caracterizado por um crescente perigo à paz mundial e de aproximação da guerra nuclear.

Em meados de 1980, já eram visíveis os limites para engendrar os avanços, em um contexto mundial marcado pela centralização capitalista avançada. No ano de 1985, em que se efetuou na Ilha a reunião dos países não alinhados na defesa do não pagamento das dívidas externas, Fidel Castro encabeçou o processo da chamada "retificação dos erros e tendências negativas", tendo em vista movimentar recursos para grandes mudanças econômicas e ideológicas, evitando assim consequências mais graves, que trariam a Perestroika para Cuba. Aprovadas as diretrizes econômicas e sociais para o período de cinco anos, de 1986 a1990, como aspecto central das retificações de erros e tendências negativas, ainda que o processo tenha encontrado extensas dificuldades, esse realinhamento implicou avanços na mobilização popular, no enfrentamento de problemas e na reafirmação do socialismo.

Com uma apreciação mais densa desse período, é possível apontar que as barreiras ao desenvolvimento cubano nos anos de 1980 foram determinados pelo alongamento de um modelo fundamentado no desenvolvimento econômico de baixa eficiência. A integração de 
Cuba ao Conselho Econômico de Ajuda Mútua (CAME), havia permitido ao país um comércio não aviltado, como nos moldes capitalistas, pois a integração funcionava segundo os princípios de equidade de seus membros, o que possibilitou o decorrer de um período tranquilo em termos de bens materiais. Nessa fase de integração, o país se beneficiou por preços especiais, créditos, ajuda técnica e acordos financeiros para os balanços comerciais. Entretanto, a falta de sustentabilidade desse modelo estava posta não exclusivamente pelo fluxo constante de recursos vindos do exterior, mas pelo desestímulo de o país buscar, a longo prazo, a diversificação da produção, fatores esses aliados ao bloqueio econômico ao qual o país estava submetido, desde os primeiros anos da revolução, à escassez de matérias-primas naturais e de fontes de energia. Os investimentos externos, oriundos de países parceiros, não haviam lançado avanços significativos no arcabouço produtivo e na balança de importações e exportações. Nesse contexto, os desafios apresentados à Revolução Cubana, no final da década de 1980, que coincidiu com a queda dos regimes do antigo campo socialista europeu, foram mais profundos do que o cenário apresentado nos discursos oficiais. A densidade dos problemas relacionava-se às heranças da época colonial e às décadas da república mediatizada, em que a estrutura monoprodutora agrária, aliadas às limitações naturais da Ilha, refletiam a necessidade de outros mecanismos de consolidação do socialismo, levando em conta as condições históricas do país.

\section{O Período Especial e a Batalha de Ideias}

Quando em 1991 foram arriadas as bandeiras da URSS, pondo um ponto final à história do Campo Socialista, surgiu a "teoria" das circunstâncias. Segundo esta, a diligência soviética havia atuado como em um tabuleiro de dominó; tocou-se a primeira peça e, em cadeia, todas as demais foram caindo. Nessa lógica, Cuba também deveria cair. Em meio a um vozerio estrondoso alguém advertiu: "não se esqueçam que essa ficha, da qual vocês falam, está demasiado distante no geográfico e no histórico” (TORRES CUEVAS, 2005, p. 31)

A década final do século XX representou para Cuba um momento de tensão e rupturas em sua experiência de construção do socialismo, com o desmoronamento da União das Repúblicas Socialistas Soviéticas (URSS). O país passou por uma etapa complexa como nação, denominada eufemisticamente de "Período Especial em Tempos de Paz", ocasião em que, segundo Rodríguez Rivera (2005, p. 132), muitos disseram: “Cuba não cai porque não tem para onde cair". 
Uma trajetória de buscas urgentes, que se estenderam durante toda a década de 1990, permitiram, em parte, ao país suplantar os períodos de maior escassez material. Contudo, não foram suficientes para assegurar o retorno às condições de vida aos patamares existentes em meados da década de 1980 .

A História de Cuba, como a de toda a América Latina, não é uma história de primeiro mundo: é a história de sua periferia. A grande crise foi motivada não só pelo desaparecimento da URSS e do Campo Socialista, mas pela crise do pensamento ocidental, em razão de seus desequilíbrios sociais e da perda de seus referenciais teóricos e históricos. O tema Cuba, numa direção ou em outra, esteve sempre presente nos debates, não excluída a avalanche dos famosos "fins". Quando da queda do socialismo na Europa Oriental, Hart Dávalos (2005, p.1) narrou uma acusação recebida: "vocês são uns náufragos" e ele imediatamente respondeu: "os náufragos nadamos até a terra firme, somos quem melhor conhecemos os motivos do acontecido e os que mais temos para contar".

Permeado por câmbios em todas as esferas da sociedade, não somente econômicos, esse contexto foi desencadeado pela queda do antigo campo socialista e pela extinção da URSS, países com os quais o país mantinha relações comerciais, que alcançavam um percentual significativo de aproximadamente $85 \%$, tanto na importação como na exportação. Essa ruptura teve consequências marcantes ao despertar expectativas, nos âmbitos interno e externo ao país, pois abarcavam elementos capazes de corroer os valores socialistas na Ilha. "Desde Washington, a consigna foi encurralar Cuba. Os Estados Unidos voltaram a aplicar contra Cuba a arcaica política da fruta madura" (FAZIO, 2018, p. 129).

Na Ilha, no bojo do Período Especial, ressurgiram diversos fenômenos que há muito se avaliavam como superados, dentre os quais o surgimento de grupos em desvantagem social. Aliada a esses componentes, emergiu uma gama de comportamentos corruptivos, incorporados ao cotidiano das empresas estatais, assim como se expandiram os negócios ilegais. Todos esses aspectos tensionaram negativamente as condições de vida da população em relação aos patamares obtidos anteriormente. Em 1991, iniciou-se um intenso período de reformas que aceleraram o recebimento legal de divisas provenientes de familiares, que residiam no exterior, e a procura de novos mercados. O projeto concebido para a resistência e sobrevida do povo, assim como para salvaguardar as conquistas do socialismo incluíam um programa agroalimentário, um plano de desenvolvimento do turismo, da biotecnologia e da indústria alimentícia. Contudo, ainda assim, os custos sociais do adensamento da crise 
econômica logo vieram à tona. Os cortes da energia por longos períodos, o uso maciço da bicicleta como meio de locomoção, o incremento de grandes ônibus para o transporte urbano, a utilização da tração animal na agricultura, caracterizaram o chamado Período Especial.

A partir da segunda metade de 1994, realizaram-se diversas mudanças socioeconômicas com muita rapidez, tais como: a despenalização da posse ilegal de divisas, o advento de várias formas de propriedade e de produção agrícola, o desenvolvimento de empresas mistas, o incremento do turismo e o surgimento do trabalho por conta própria, fatores levados em conta na hora de formular o projeto educativo da escola pretendida na sociedade socialista. Até o final da década de 1980, a forma estatal era a principal configuração de propriedade sobre os meios de produção em Cuba, alcançando quase que a sua totalidade. Esse cenário começou a ser alterado com a reforma constitucional realizada em 1992, em que se reconheceram outras formas de propriedade. Como consequência, em 1998, Cuba já registrava 260 associações econômicas com o capital internacional (NOGUERA, 2004).

Com o agravamento das condições econômicas e a abertura do país ao investimento estrangeiro, muitos professores migraram para setores melhor remunerados, ligados ao turismo, como a confecção e venda de artesanato, o trabalho em pequenos restaurantes privados, o emprego na rede hoteleira, o aluguel de cômodos em suas próprias casas e inúmeras outras atividades, algumas submetidas à regulação estatal e outras "piratas", como são conhecidos os motoristas de táxis clandestinos, os produtores de discos falsificados, de refrigerantes caseiros e demais "inventos", no dizer dos cubanos, sempre criativos em suas idiossincrasias.

De acordo com Rodríguez Rivera (2005, p. 66), o governo revolucionário implementou medidas, "com a melhor das intenções, com o intuito de fazer justiça e de conseguir o máximo de igualdade"; entretanto, elas têm sido sistematicamente violadas pela população, uma vez que, no entendimento corrente, as necessidades são uma questão de sobrevivência. Movendo-se entre acatar as leis e violá-las, "o cubano concebeu um jogo de dupla moral, num par dialético equivocado e numa advertência aos legisladores que não conseguem senão desacreditar a legalidade das medidas concebidas para ser burladas, em razão de sua irrealidade" (ibid., p. 67).

Todos esses processos decorrentes da crise adentraram ao campo da Educação cubana de forma significativa. As dificuldades inerentes à conjuntura de limitações materiais constituem um fator de conflito na puberdade e na adolescência, implicando 
redimensionamento do papel que os filhos ocupam no lar. "Esta etapa serve de balanço para todos: submetem-se ao juízo a convivência familiar, os empenhos educativos dos adultos e a influência das instituições socializadoras, inclusive a escola”, nas palavras de Castro Alegret (2002, p. 58).

Em 1996, como resultado das contradições surgidas no projeto educacional, a atividade científica em Cuba apresentava deficiências relacionadas à falta de gestão integrada. As instituições elaboravam planos independentes, ocasionando a dispersão do potencial científico no país. Em muitos casos, não se investigava o prioritário, predominando o enfoque unidisciplinar. De acordo com Castellanos Simons (2001), os aspectos negativos vigentes eram:

- A consciência igualitarista, originada ao longo do processo revolucionário, havia fomentado a ideia de bem-estar material, desconectada das possibilidades reais do país e da contribuição laboral de cada cidadão, o que resultou no debilitamento do trabalho como dever social concreto.

- A fragmentação das instituições socializadoras, em especial a escola e a família, que não atuavam de forma coordenada, fortalecendo as influências negativas de grupos coetâneos e os comportamentos indesejados, tais como as atitudes consumistas.

- A tecnocratização, ou seja, a Educação dirigida às informações de caráter prático, em detrimento da formação humanista, o que enfraqueceu a flexibilização para os ajustes à realidade em constantes mutações.

- O excesso de tutela na Educação, de forma a reduzir a participação ativa dos jovens nas tarefas sociais e a capacitação na área profissional.

Os estudos elaborados pelo Instituto Central de Ciências Pedagógicas reconheceram que os impactos das transformações sociais, suscitavam a reavaliação do papel da escola e a implementação de programas inseridos em uma revolução técnico-científica, assim como em ações para minimizar o impacto nocivo da globalização neoliberal. Cabe destacar a realização de um amplo processo de reestruturação de espaços culturais, laboratórios e bibliotecas.

A etapa de reanimação da economia ocorreu no final da década de 1990, quando Cuba conseguiu implementar seus planos de desenvolvimento, em especial o incremento do turismo, para a entrada de moedas fortes no país. Esse novo contexto permitiu ao Estado priorizar a cultura integral à toda a população. O Programa Batalla de Ideas, desencadeado 
em 1999, é um conjunto de ações que se desenrolam para oferecer uma cultura geral e integral aos cubanos e incluem estratégias para: eliminar a desigualdade que possa ter sido gerada como consequência do período de crise em todas as esferas da sociedade; dar prioridade aos projetos voltadas aos setores mais vulneráveis da população; obter uma sociedade sem desempregados e sem presos, e garantir, a todos os cidadãos, não somente igualdade de oportunidades, mas também de possibilidades. A política de emprego foi uma área priorizada no âmbito das estratégias, que estiveram centradas na requalificação de trabalhadores, desocupados ou vinculados a unidades produtivas desativadas, e na concretização de um programa denominado "emprego para estudar", que envolvia investimentos educacionais para a formação de futuros profissionais.

Inserida no Batalla de Ideas, a universalização da Educação Superior, como parte da Terceira Revolução Educacional, envolveu vários subsistemas, dentre eles a Formação e o Aperfeiçoamento do Pessoal Pedagógico, com base nas experiências de formação emergente. Em todos os bairros, diversos hospitais, escolas e fábricas foram convertidos em sedes universitárias, concebidas como microuniversidades. O conceito de universalização não foi concebido exclusivamente para formação de professores, uma vez que nas sedes coloca-se o universitário de todas as carreiras em contato com a realidade de sua profissionalização.

No ano 2001, iniciou-se a construção do método Yo sí puedo, que combinaria números e letras para ensinar leitura e escrita a adultos, por meio do uso de recursos audiovisuais. O programa foi concebido com um caráter internacionalista, especialmente latino-americano, preparado para ser adaptado aos diferentes contextos sociais e linguísticas. Seu objetivo fundamental é a inserção ativa dos participantes nas tarefas sociais, econômicas e políticas da comunidade do país em que vivem. Até agora, com resultados positivos, as campanhas do método foram realizadas em Haiti, Venezuela, Bolívia, Brasil, México, Argentina, Equador, Peru, Honduras, Nicarágua, República Dominicana, Granada, Nova Zelândia, Moçambique, Guiné-Bissau, Colômbia, El Salvador, Uruguai e Guatemala, entre outros.

\section{As Novas Diretrizes: avanços e rupturas}

Hay injusticia en pedir a la aurora todo el vigor y la claridad do día.

(JOSÉ MARTÍ) 
A década final do século XX representou para Cuba um momento de tensão e de rupturas na experiência de construção do socialismo, como consequência da entrada em cena do mundo praticamente unipolar. Nessas condições, expandiu-se uma economia informal e o trabalho por conta própria em razão tanto das limitações do controle administrativo, como de ineficiência na distribuição e de carências recorrentes. Por outro lado, a depressão dos salários reais, inicialmente compreendidas como um símbolo da partilha equitativa dos custos da crise e o subsequente ajustamento, era um problema concreto a ser enfrentado. $\mathrm{O}$ valor do emprego público estatal foi quebrado, passando a ser visto como sinônimo de estreiteza e incapacidade de subir na pirâmide social. Diante dessa situação, as famílias projetaram e colocaram em prática um conjunto de estratégias para garantir a própria viabilidade econômica.

Em 2005, novas limitações da economia cubana eram evidentes no déficit financeiro do balanço de pagamentos, nas transferências bancárias ao exterior e na grande quantidade de vencimentos de dívida. No ano de 2007, foi realizado um chamamento popular, que mobilizou mais de cinco milhões de pessoas, dando lugar a 1.300.000 encaminhamentos de onde foram extraídas as novas diretrizes resumidas nos Lineamientos de la Política Económica y Social del Partido y de la Revolución e aprovadas no $6^{\circ}$ e no $7^{\circ}$ Congressos do Partido Comunista de Cuba ${ }^{16}$, para os períodos de 2011 a 2015 e de 2016 a 2030, respectivamente.

Além das transformações estritamente econômicas, mesmo antes do $6^{\circ}$ Congresso, outras permissões de impacto na vida diária já haviam sido implementadas: a aquisição de telefones celulares, a hospedagem de cidadãos cubanos em hotéis internacionais com pagamentos em divisas, o acesso limitado à Internet e a compra e venda de imóveis.

No denominado Proceso de Actualización del Modelo Económico, centrado nas esferas econômicas e organizacionais da sociedade cubana, o desenrolar do trabalho por conta própria, - o denominado cuentapropismo -, vem apresentando momentos de potencialização e etapas de estigmatização. Depois da realização do $7^{\circ}$ Congresso, nos espaços intelectuais, políticos e da vida cotidiana em Cuba, gerou-se uma grande polêmica em torno de seu papel no presente e no futuro do país, uma vez que não se trata apenas de uma questão econômica, mas também de transformações nos planos ideológico e cultural.

\footnotetext{
${ }^{16}$ Os $6^{\circ}$ e $7^{\circ}$ Congressos do Partido Comunista de Cuba, foram realizados na cidade de Havana em abril de 2011 e abril de 2016, respectivamente.
} 
Entre as alternativas para dar emprego às pessoas disponíveis, pela restruturação de empresas, e aos indivíduos que não se motivavam a trabalhar para o estado cubano, destaca-se a ampliação de diversas práticas não subordinadas diretamente à administração estatal, sendo que as atividades mais representativas deste setor cuentapropista são: a elaboração e comercialização de alimentos, o transporte de cargas e passageiros, a locação de casas, quartos e espaços, bem como a contratação de mão de obra associada principalmente a essas atividades. Com medidas reconhecidamente válidas por todas as organizações de massa e necessárias ao desenvolvimento sustentável, a adoção do trabalho por conta própria, introduziu em Cuba mais de duzentos ofícios exercidos de forma individual ou em cooperativas, tais como, pedreiro, eletricista, pintor, manicure, barbeiro, costureira, marceneiro, borracheiro, relojoeiro, cabelereiro, tapeceiro e sapateiro, entre outros.

As alterações nos ingressos monetários ocorridas nos últimos anos não foram apenas provenientes da ampliação do setor não estatal. A liberação para a posse e o uso de divisas impulsionou as remessas de dinheiro dos parentes no exterior aos familiares em Cuba. Essa fonte de obtenção de melhores rendimentos, que não está relacionada ao trabalho, tampouco ao aumento da produção interna, acabou apresentando um peso significativo na diferenciação do nível de vida alcançado pelas famílias, em meio a um novo recrudescimento do bloqueio econômico, comercial e financeiro ininterrupto, que durante mais de meio século é imposto pelos Estados Unidos a Cuba.

Quando se tenta aprofundar e compreender os processos que envolvem as transformações em Cuba, o quadro que se apresenta é extremamente complexo, adota múltiplas formas e transcorre em espaços, tempos e situações variadas. A busca de respostas positivas ao enfrentamento dos problemas, que se configuraram após a crise global do novo milênio, está calcada na experiência acumulada na esfera educativa, nos centros de pesquisa, incluindo as universidades. Em 2009, no bojo das transformações, o Ministério da Educação empreendeu um plano com o objetivo de continuar elevando a qualidade da Educação e assim garantir que as futuras gerações estejam preparadas para enfrentar os desafios gerados pelo próprio desenvolvimento. Com esse intuito, foram priorizados o trabalho político-ideológico e a Educação em valores, em todo o Sistema de Ensino, sustentados em maior conhecimento da História cubana e universal. O novo modelo incluía 21 carreiras docentes nas Universidades de Ciências Pedagógicas em toda a Ilha. 
No texto da atual constituição aprovada em referendo ${ }^{17}$, no Título III, estão descritos os Fundamentos da Política Educacional, Científico e Cultural. Seu artigo 32 assinala: “O Estado orienta, incentiva e promove a educação, as ciências e a cultura em todas as suas manifestações" (CUBA, 2019). Para alcançar seus objetivos, segundo a nova carta magna cubana, o Estado deve combinar a educação geral e científica especializada, técnica ou artística, com o trabalho, com o desenvolvimento de pesquisas, com a educação física e os esportes, com a participação em atividades políticas.

No período em que a denominada geração histórica ${ }^{18}$ está deixando os cargos diretivos, com a economia em moderadíssimo crescimento, as novas diretrizes buscam a distribuição equitativa dos frutos de parcos avanços e a inclusão dos grupos em desvantagem social, que sofreram com a grande crise do denominado Período Especial. Dentro deste cenário, o Sistema Nacional de Educação realiza o III Aperfeiçoamento, após a revolução, que se iniciou experimentalmente em 2014 e deve ser consolidado até 2030 . O $6^{\circ}$ Congresso do Partido Comunista de Cuba, realizado em abril de 2011, aprovou as Diretrizes da Política Econômica e Social do Partido e da Revolução, nos quais se buscava, de acordo com o proposto, dar continuidade à melhoria da Educação e atualizar os programas de formação continuada e pesquisa nas universidades em função do desenvolvimento econômico e social do país e das novas tecnologias. O conteúdo destas diretrizes exigiu que o ensino superior realizasse uma revisão dos programas dos cursos e modificações na concepção do currículo por programas das disciplinas de todos os níveis, visando ao desenvolvimento de profissionais cubanos em correspondência aos novos cenários e às condições complexas vislumbradas para as próximas décadas. Na concepção dos novos planos, a formação dos educadores é considerada uma tarefa estratégica para o desenvolvimento da sociedade socialista.

A inserção de Cuba no contexto socioeconómico altamente competitivo implica a busca de espaços, que permitam obter os conhecimentos e recursos necessários para atender a demanda de aperfeiçoamento do setor produtivo, a renovação tecnológica, assim como

\footnotetext{
17 A Assembleia Nacional de Cuba aprovou dia 22 de dezembro de 2018 o projeto da nova Constituição do país, que foi submetido a referendo popular em 24 de fevereiro de 2019 . O texto constitucional reconhece a propriedade privada e mantém o Estado como o principal pilar da economia cubana. A proposta, antes de ser submetida à votação na Assembleia Nacional, foi levada a consulta popular entre agosto e novembro de 2018. No texto é destacado o caráter socialista de revolução.

${ }^{18}$ Em fevereiro de 2018, Raúl Castro deixou a presidência para seu sucessor, o professor Miguel Dias-Canel.
} 
atender a gestão dos recursos humanos, em especial a adequada educação técnica e profissional do trabalhador.

\title{
Algumas Considerações
}

\begin{abstract}
De um lugar onde se escuta o canto das sereias, que nos convoca a sermos o que não somos, nós, os cubanos, persistimos em nossa identidade, que nos faz incólumes a todas as influências. Quanto mais se acerca de uma influência devastadora, mais regiamente o cubano resiste em deixar-se dominar por ela. Assim opera a ingravide ${ }^{19}$, essa volubilidade de um país regido pelas brisas, sempre hábil para escapar de todos que tentam transformá-lo, por ter uma alma inalcançável, que nem ele mesmo conhece em sua plenitude (RODRIGUEZ RIVERA, 2005, p. 59).
\end{abstract}

Das revoluções ocorridas em Cuba, a historiografia cubana permite mais do que uma mera relação de assuntos bélicos. A análise dos conflitos, por diversos ângulos, demonstra que suas consequências se estendem até os nossos dias. Os mais de cento e cinquenta anos marcados por fatos e homens, com sua carga de ensinamentos, fizeram com que a nação cubana tomasse consciência de que as contradições internas desencadearam a ingerência de forças expansionistas de potências estrangeiras. Em meio à complexidade desse processo, é necessário reconhecer os anseios próprios dos cubanos, propensos a entrelaçar a trajetória pessoal com a trama histórica do país, a qual oscila, de uma forma periódica, entre o passado de lutas, o presente marcado por dificuldades e os interrogantes do futuro.

A história aponta que a Educação em Cuba vem traçando pautas para consolidar um corpo de resistência, em que os coletivos das escolas, contornando a perspectiva de soluções pessoais, são orientados a um trabalho na defesa dos princípios do socialismo. Contudo, a esta altura do processo revolucionário, resta saber se o caldo de práticas acumuladas ao longo de sessenta anos na formação de professores, será capaz de trabalhar os problemas atuais de forma abrangente e com a urgência requerida pela complexidade do processo histórico cubano.

A campanha de alfabetização, na década de 60, significou, mais que uma estratégia educacional, uma experiência profunda para transformar o triunfo do movimento 26 de julho em vitória política, consolidadora do projeto societário, no qual a elevação cultural caminhou

\footnotetext{
${ }^{19}$ A teoria da "fruta madura" fazia alusão à inevitabilidade de que Cuba cairia nas mãos dos Estados Unidos, quando se desprendesse da Espanha. Entretanto, segundo Rodriguez Rivera (2005, p. 59), a fruta amadureceu e segue contrariando a lei da gravidade.
} 
junto às lutas contra a dominação estrangeira. Analisando, em dimensão abrangente, pode-se dizer que o objetivo maior foi conseguido: tirar a população da inércia habitual e mobilizá-la coletivamente, transformando antigos traços culturais de acomodamento em relação à ação paternalista das autoridades. Contudo, uma análise apurada das últimas décadas vem corroborando no sentido de demonstrar que apenas com lições não se forja uma nova postura, uma nova ética, diante da necessidade de os jovens participarem do esforço coletivo. $O$ fato de os meios de produção serem supostamente acatados como patrimônios do povo não se traduz em um anseio coletivista, se homens e mulheres, jovens e adultos, trabalhadores e estudantes não se sentirem, diante de tais meios, como produtores e administradores. A passividade imposta aos jovens nos processos de socialização e a influência de padrões externos, sobretudo dos chamados "comunitários" 20 , conformaram um modelo social embasado no consumo e com tendências à mentalidade de consumidor acima da consciência de produtor, problemas que dificultam a consolidação da escola na esfera dos valores, especialmente na faixa etária mais vulnerável, que é a adolescência. Não obstante, apesar dos recentes câmbios econômicos e da ampliação do trabalho por conta própria, a maioria da juventude cubana se encontra vinculada ao setor estatal. Isso está, provavelmente, relacionado ao fato de que o Estado cubano continua priorizando a inclusão de jovens em seus órgãos e entidades. A decisão de orientar as estruturas a uma economia mista parece indicar que, apesar das persistentes deficiências sociais, existe uma mobilização consolidada para enfrentar os enormes desafios presentes em 2019.

Em meio às tentativas de evitar que a corrupção comprometa o sistema produtivo em expansão, as reformas educativas em Cuba tendem a caminhar em conjunto com os planos atuais, que não são exclusivamente econômicos, mas envolvem as esferas políticas e de valores. A intencionalidade declarada nas práticas e nos discursos é conseguir um alto nível de ideologização do ensino, negando a exterioridade comum à maioria dos sistemas educativos em outros países, caracterizados pela suposta ausência de cunho ideológico, sob uma pretendida dimensão técnica, que tende a ser apreendida como neutra no senso comum. Todavia, considerando os sinais de deterioração dos princípios identificados com a ética da Revolução, verificam-se múltiplos impasses. Pintada de luzes e de sombras, como é natural, a adoção do trabalho por conta própria vem comprovando ser um recurso válido e

${ }^{20}$ Em Cuba, é usual a expressão "comunitários" para designar os cubanos da comunidade de residentes no Estado da Florida. 
irreversível, por constituir um campo emergente na economia em Cuba. A dúvida posta em jogo é se o desequilíbrio de salários entre os setores estatal e não estatal, irá comprometer ou provocar uma evasão de quadros necessários ao bom desempenho dos organismos do Estado.

Sobre as dificuldades, no que tange ao processo de acumulação e ampliação da capacidade de produção de riquezas, cabe rememorar que Cuba enfrentou hostilidades extremadas nos primeiros anos da revolução, quando, além da fuga dos quadros profissionais qualificados, o país precisou alterar o sistema produtivo em razão das dificuldades em adquirir peças de reposição, com o padrão tecnológico herdado. Depois, com o fim dos regimes no leste europeu, o país novamente enfrentou grandes adversidades. Entre as novas e as velhas contradições, Cuba segue propondo uma revolução contra as oligarquias e contra os dogmatismos. É certo que em todos os campos, inclusive da Educação, o movimento revolucionário enfrentou problemas que nem sempre conseguiu resolver, em razão do bloqueio de sessenta anos e aos incontáveis assédios, por parte das corporações imperialistas e do complexo mediático hegemônico no mundo.

Transcorrida uma década, desde início das novas diretrizes, o país mantém os mecanismos de distorção quanto aos ingressos monetários no setor estatal e continuam as fragilidades quanto às garantias dos trabalhadores do setor não estatal. Apesar dos avanços e dos embates, é possível afirmar que o Proceso de Actualización del Modelo Económico é o mais profundo desde o triunfo da Revolução Cubana. Passados doze anos, no período de 2007 a 2019, desde que em Cuba se apontou a necessidade de introduzir mudanças estruturais, as avaliações parecem indicar que o equilíbrio macroeconômico básico apresenta avanços, mas sem resolver definitivamente as limitações de ordem material na Ilha. O incremento do turismo internacional, os investimentos estrangeiros em Cuba e o acesso ampliado à Internet representam fatores de alta incidência na crescente integração da Ilha ao mundo.

Para quem pensa a Revolução Cubana, sem prejudicialidade, os indícios apontam que seus dirigentes trataram, por todas as formas, de encontrar soluções originais aos problemas enfrentados, em todas as fases e em todos os momentos. Uma das consequências esperadas no processo de atualização do modelo econômico e social de Cuba é a manutenção do principal patrimônio do país - a sua força laboral qualificada -, alavancando as respostas esperadas. 
As transformações em curso são de magnitude significativa e vários elementos sugerem que essa tendência pode se acelerar nos próximos anos. No quadro atual, é possível afirmar que as novas fontes de trabalho, fora do setor estatal, não correspondem ao nível do grande investimento na Educação empreendido em sessenta anos. Em consequência, Cuba busca a atualização, sob um modelo ajustado às necessidades e ao aproveitamento de seus quadros, cujas linhas gerais foram defendidas no $7^{\circ}$ Congresso do Partido. A grande expectativa, ao que tudo indica, irrealizável a curto e médio prazos, seria a eliminação das sanções impostas pelos Estados Unidos. A tarefa mais árdua começa agora e um elemento de grande calibre pesa sobre o futuro próximo: desde o ano de 2016 a economia cubana entrou em outro ciclo recessivo, mais uma vez originado pelas dificuldades do maior aliado comercial de Cuba, neste caso a Venezuela. O cenário internacional tornou-se menos favorável, especialmente em relação aos parceiros das últimas décadas na América Latina.

Para concluir estas análises, pondera-se que a escola tem colaborado acentuadamente para estabelecer em Cuba um quadro diferente do nível de desagregação social, que marca as grandes cidades da América Latina e do Caribe, onde a violência entrópica demonstra um fosso enorme de separação daquilo que seriam as sociedades razoavelmente justas. No entendimento desta pesquisa, a distância entre os pertencentes aos grupos em "desvantagem social" e os que conhecem a "filiação", se é possível assim chamá-los dentro do formato societário cubano, não inclui a precariedade brutal que mantém as massas em estado de alerta contra assaltos à mão armada, sequestros e outras formas de criminalidade frequentes nos países alinhados ao capitalismo da era globalizada. Esta análise não exclui o registro da precariedade de moradias, especialmente nas zonas de grande concentração urbana de Havana, as deficiências no abastecimento de água e energia elétrica, as dificuldades no serviço de transporte e no recolhimento de lixo urbano. É possível salientar ainda que as limitações engendradas na crise surgida com o Período Especial não acarretaram o abandono de prédios escolares, o fechamento de hospitais, o fenômeno dos "meninos de rua" e de populações excluídas pelo sistema de saúde. Por mais que as instituições cubanas tenham sido afetadas em sua estrutura, a escola ainda representa um papel fundamental, como alicerce do processo revolucionário cubano e como igualadora social, por suposto, de forma distinta dos valores e das aspirações que vigoram nos países centrais de acumulação capitalista. 
A história de Cuba, desde a chegada com colonizadores até hoje, é tudo, menos estática. A cubanía, erguida ao longo de quinhentos anos, consolida as bases de um país único, com suas conquistas, debilidades, fortalezas e identidade. O caráter dos cubanos tem reforçado o significado das raízes autóctones, trazendo à luz a reação contra uma pretensa universalidade que vem de fora, de um mundo dominado ora por Portugal-Espanha, ora pela América do Norte ou, mais recentemente, pelos ditames da globalização, que reiteram um desejo de autenticidade, com apoiado na tradição vinculada a Varela, Martí e Mella.

Em meio aos caminhos que têm sido construídos, existem dilemas e tensões difíceis de resolver, inscritos na problemática geral da realidade cubana, sobretudo no conflito entre a lógica da emancipação e da regulação. Tudo indica, porém, que os avanços devem ser equacionados como parte das políticas contra-hegemônicas, em oposição ao contexto que instaurou a volta de um capitalismo racionalizado e excludente em grande parte do mundo. A conclusão desse exercício reflexivo assinala a vigência do ideário martiano, toda vez que as políticas internacionais contemporâneas tendem a realizar o que era incipiente no século XIX: desprezar o significado do autêntico e do genuíno, para dar asas ao colonialismo e ao neocolonialismo disfarçados de universalidade.

\section{Referencias}

ACOSTA, Leonardo. José Martí: el indio de nuestra América. La Habana: Centro de Estudios Martianos, 2015.

BALIÑO, Carlos. El suicidio de los niños. In Instituto de historia del movimiento comunista y de la revolucion socialista de Cuba (org.). Carlos Baliño: documentos y artículos. La Habana: Departamento de Orientación Revolucionaria del Comité Central del Partido Comunista de Cuba, 1976.

BARNET, Miguel. Biografía de un cimarrón. Buenos Aires: Centro editor de América Latina, 1977.

BLANCO CASTIÑNEIRA, Katiuska. Fidel, el monte en la piel. In: SAXE-FERNÁNDEZ John. Yo soy Fidel: pensamiento y legado de una inmensidad histórica. Buenos Aires: Clacso, p. 21-46, 2018.

BUENAVILLA RECIO, Rolando et al. Historia de la pedagogía en Cuba. La Habana: Pueblo y Educación, 1995.

CALDAS, Camilo Onoda Luiz. Teoria Geral do Estado. São Paulo: Ideias \& Letras, 2018. 
CANFUX GUTIÉRREZ, Jaime et al. La alfabetización: historia y autenticidad en Cuba. La Habana: Pueblo y Educación, 2006.

CANTÓN NAVARRO, José. Una revolución martiana y marxista. La Habana: Centro de Estudios Martianos, 2008.

CASTELLANOS SIMONS, Doris et al. Aprender en la escuela: una concepción desarrolladora. La Habana: Instituto Superior Pedagógico “Enrique Jose Varona”, 2001.

CASTRO ALEGRET, Pedro Luis. Cómo la familia cumple su función educativa. La Habana: Pueblo y Educación, 2002.

CHACÓN ARTEAGA, Nancy. Educación Ética y en Valores para una cultura de Convivencia y Paz desde una perspectiva cubana. México: Editorial Redipe, 2017.

CHÁVEZ RODRÍGUEZ, Justo. Las Ideas de José Martí sobre educación. In: TURNER, Lidia et al. Martí y la educación. La Habana: Pueblo y Educación, 1996.

CIRULES, Enrique. O Império de Havana. São Paulo: Página Aberta, 1995.

CUBA (República de). La Educación en Cuba. In: PEDAGOGÍA 99: Encuentro por la unidad de los educadores. La Habana, 1999.

Constituição de 2019. Disponível em:

http://www.granma.cu/file/pdf/gaceta/Nueva\%20Constituci\%C3\%B3n\%20240\%20KB-1.pdf (Acesso em agosto de 2019). Cuba, 2019.

CUPULL, Adys e GONZÁLEZ Froilán. Julio Antonio Mella: Biografia. Ciudad de La Habana, Cuba: Casa Editora Abril, 2010.

FAZIO, Carlos. Fidel y la pedagogía de una revolución. In: SAXE-FERNÁNDEZ John. Yo soy Fidel: pensamiento y legado de una inmensidad histórica. Buenos Aires: Clacso, p. 103138, 2018.

FERNANDES, Florestan. Da Guerrilha ao socialismo: a revolução cubana. São Paulo: Expressão Popular, 2007.

FERNÁNDEZ ÁLVAREZ, José Ramón. Un hombre afortunado. La Habana: Casa Editorial Verde Olivo, 2018.

FERNÁNDEZ RETAMAR, Roberto. Martí en su (tercer) mundo. In: Introducción a José Martí. La Habana: Editorial Letras Cubanas, p. 13-79. 2001.

GONZÁLEZ SOCA, Ana Maria; REINOSO CÁPIRO, Carmen. Nociones de sociología, psicología y pedagogía. La Habana: Pueblo y Educación, 2002.

HARNECKER, Marta. Fidel: La Estrategia Política de la Victoria. La Habana: Editorial de Ciencias Sociales, 2001. 
HART DÁVALOS, Armando. Marx, Engels y la condición humana: una visión desde Cuba. La Habana: Ciencias Sociales, 2005.

MARTÍ, José. Obras completas. La Habana: Ciencias Sociales, 1975.

2011.

Obras Completas, Edición Crítica. La Habana: Centro de Estudios Martianos,

MARTÍNEZ HEREDIA, Fernando. Nación y sociedad en Cuba. In: En el horno de los noventa. La Habana: Editorial de Ciencias Sociales, p. 185-197. 2005.

NOGUERA, Albet. Estructura social y igualdad em la Cuba actual: La reforma de los noventa y los cambios em la estructura de clases cubana. Revista Europea de Estudios Latinoamericanos y del Caribe, [S.I.], n. 76, p. 45-59, 2004.

OBAYA MARTÍNEZ, Alicia. La Edad de Oro: definición y práctica de las principales concepciones pedagógicas martianas. In: TURNER, Lidia et al. Martí y la educación. La Habana: Pueblo y Educación, p. 42-48. 1996.

PÉREZ JR, Louis A. Ser cubano: identidad, nacionalidad y cultura. La Habana: Editorial Ciencias Sociales, 2016a.

. Cuba en el imaginario de los Estados Unidos. La Habana: Editorial de Ciencias Sociales. 2016b.

POGOLOTTI, Graziella. Palabras inicias. Revista da Universidad de La Habana, n.245, p .56, ene./-dic.1995.

RODRÍGUEZ RIVERA, Guillermo. Por el camino del mar: los cubanos. La Habana: Boloña, 2005.

SOSA RODRÍGUEZ, Enrique e PENABAD FÉLIX, Alejandrina. Historia de la educación en Cuba. La Habana: Pueblo y Educación, 1997.

TORRES CUEVAS, Eduardo. Prólogo. In: HART DÁVALOS, Armando. Marx, Engels y la condición humana. La Habana: Editorial de Ciencias Sociales, p.125-186, 2005.

UNESCO. Educación para todos, el imperativo de la calidad: informe de seguimiento da la EPT en el mundo. Paris: Organización de las Naciones Unidas, 2005.

VARONA DOMÍNGUEZ, Freddy. Humanismo, ideario de José Martí y pensamiento marxista cubano. La Habana: Editorial Félix Varela, 2013.

VITIER, Cintio. Ese Sol del mundo moral. La Habana: Centro de Estudios Martianos, 2011. 


\title{
Estado, identidade e educação: cento e cinquenta anos de resistências e lutas em Cuba
}

\section{Resumo}

O presente artigo está dirigido ao estudo das transformações, que abarcam o projeto societário e tendem a caminhar em conjunto com os contextos históricos em Cuba. Apresentam-se aspectos do tensionamento entre a insurgência e a invasão estrangeira, desde a dominação espanhola, passando pela república mediatizada, até a presente conjuntura de mudanças, período em que a chamada geração histórica está deixando os cargos diretivos. A discussão tem os seus alicerces fincados na visão retrospectiva dos dilemas e das tensões presentes na construção da cubanía, que vem delineando pautas à população em todas as épocas. As análises são traçadas em sentido contrário à visão eurocentrista, que recorta os esforços de compreensão relacionados às revoluções cubanas, incluindo as inconclusas e as vitoriosas dos séculos XIX e XX, abarcando um período de 150 anos, em que as raízes da cubanidade foram materializadas. As principais evidências deste exercício reflexivo, apontam que a história da Ilha produziu uma cultura de características autóctones com reflexos no sistema educativo e que as instituições escolares, afetadas por dificuldades de várias ordens, ainda assim, se apresentam como a pedra angular do processo revolucionário cubano, que tem na Educação a grande igualadora social do país.

Palavras-chave: identidade cubana; educação cubana; revolução cubana; cubanía; legado martiano; história de Cuba.

\section{Estado, Identidad y Educación: ciento cincuenta años de resistencias y luchasn Cuba}

\section{Resumen}

Este artículo está dirigido al estudio de a las transformaciones que abarcan el proyecto societario y tienden a manifestarse en conjunto con los contextos históricos en Cuba. Se presentan aspectos de la tensión entre la insurgencia y la invasión extranjera, desde la dominación española, a través de la república mediatizada, hasta la actual coyuntura de cambios, período en el que la llamada generación histórica se aleja de las posiciones de liderazgo. La discusión tiene sus bases establecidas en la visión retrospectiva de los dilemas y tensiones presentes en la construcción de la cubanía, que ha estado delineando pautas para la población en todas las épocas. Los análisis se esbozan en la dirección opuesta a la visión eurocentrista, que recorta los esfuerzos de comprensión relacionados a las revoluciones cubanas, incluidas las no concluyentes y las victoriosas de los siglos XIX y XX, que abarcan un período de 150 años, en el que se materializaron las raíces de la cubanidad. Las principales evidencias de este ejercicio reflexivo señalan que la historia de la Isla produjo una cultura de características autóctonas con reflejos en el sistema educativo y que las instituciones escolares, afectadas por dificultades de varios órdenes, se presentan como la piedra angular. del proceso revolucionario cubano, que tiene en la educación el gran igualador social del país.

Palabras clave: identidad cubana; educación cubana; revolución cubana; cubanía; legado martiano; historia de Cuba.

\section{State, Identity and Educacion: one hundred and fifty years of resistance and struggle in Cuba}

\begin{abstract}
This article refers to the study of the transformations that encompass the society project and tend to follow the historical context in Cuba. Aspects of the tension between the insurgency and the foreign invasion are observed from the Spanish domination, through the mediatized republic, to the present conjuncture of changes, period in which the so-called historical generation is leaving the leadership positions. The discussion has its foundations in the retrospective view of the dilemmas and tensions associated to the construction of cubanía, which has always been the guidelines for the population in all periods. The analyzes are defined in the opposite direction to the eurocentrist vision, that disregards the aspects related to the Cuban revolutions, including the inconclusive and the victorious ones of the XIX and XX centuries, covering a period of 150 years, in which the roots of the cubanidad were materialized. The main evidences of this reflexive exercise demonstrates that the history of the Island produced a base culture of autochthonous characteristics with reflexes in the educational system and that the schools, despite of being affected by difficulties of several orders, represent the cornerstone of the Cuban revolutionary process, which makes Education as the great social equalizer in the country.
\end{abstract}

Keywords: Cuban identity; Cuban education; Cuban revolution; cubanía; Martí legacy; history of Cuba. 